\title{
Estabilidade aeróbia de silagens de capim-mombaça tratadas com Lactobacillus buchneri ${ }^{1}$
}

\section{Carla Luiza da Silva Ávila ${ }^{2}$, José Cardoso Pinto ${ }^{3}$, Henrique César Pereira Figueiredo ${ }^{4}$, Augusto Ramalho de Morais ${ }^{5}$, Odilon Gomes Pereira ${ }^{6}$, Rosane Freitas Schwan ${ }^{7}$}

\author{
1 Projeto financiado pelo CNPq. \\ 2 Pós-doutorado em Zootecnia - UFLA \\ ${ }^{3}$ Departamento de Zootecnia - UFLA. \\ ${ }^{4}$ Departamento de Medicina Veterinária - UFLA. \\ ${ }^{5}$ Departamento de Ciências Exatas - UFLA. \\ ${ }^{6}$ Departamento de Zootecnia - UFV. \\ 7 Departamento de Biologia - UFLA.
}

RESUMO - Objetivou-se avaliar o efeito da adição de duas cepas de Lactobacillus buchneri sobre a estabilidade aeróbia de silagens de capim-mombaça. O experimento foi conduzido em delineamento inteiramente casualizado com três repetições, em esquema de parcelas subdivididas no tempo, de modo que os tratamentos (silagens sem inoculantes e com inoculante experimental e comercial) foram aleatorizados nas parcelas e os tempos de avaliação aeróbia das silagens (0, 2, 8 ou 10 dias após a abertura dos silos) nas subparcelas. Após 90 dias de armazenamento, os silos foram abertos e amostras de aproximadamente $2,5 \mathrm{~kg}$ foram retiradas para avaliação da estabilidade aeróbia com base na temperatura de cada amostra. As mudanças químicas e microbiológicas foram avaliadas. Após abertura dos silos, verificou-se aumento nas populações de bactérias do ácido lático, leveduras e fungos filamentosos. Houve aumento nos valores de pH resultante da redução da concentração dos ácidos orgnicos e de aumentos dos teores de matéria seca e proteína bruta. A adição de L. buchneri às silagens melhorou sua estabilidade, enquanto a silagem sem inoculante apresentou estabilidade de 55 horas. As silagens inoculadas não ultrapassaram essa temperatura limite em um período de 10 dias. A melhoria da estabilidade foi ocasionada pela associação de altas concentrações de cido acético ao ácido propiônico e pela menor concentração de ácido lático no momento de abertura, o que inibiu a proliferação de fungos filamentosos e leveduras após abertura dos silos.

Palavras-chave: ácido acético, ácido lático, fermentação, microbiologia, temperatura

\section{Aerobic stability of mombaça grass silages treated with Lactobacillus buchneri}

\begin{abstract}
This study aimed to evaluate the effect of the addition of two L. buchneri strains on the aerobic stability of the Mombaça grass silages. The experiment was carried out in a completely randomized design with three replicates in split-plot in time scheme, so that the treatments (silages without inoculant and with experimental or commercial inoculants) were randomized on plot and in times of aerobic evaluation of the silages $(0,2,8$, and 10 days after the opening of the silos) as subplots. After an storage period of 90 days, the silos were opened and samples of about $2,5 \mathrm{~kg}$ were collected for the evaluation of the aerobic stability based on the temperature for each sample. The chemical and microbiological changes in the silages were evaluated. As soon as the silos were opened, changes in the silages were observed, with increases in the lactic acid bacteria, yeast and filamentous fungus populations. Also, the $\mathrm{pH}$ values increased due to the reduction in the organic acids concentration and to the increase in the DM and CP contents. The addition of L.buchneri to the silages increased their stability. The silages without inoculant was stable for 55 hours. The inoculated silages remained stable for 10 days. The improved stability was a consequence of an association of high acetic acid concentration with propionic acid and lower lactic acid concentration at the moment of silo opening, which resulted in inhibition of yeasts and molds.
\end{abstract}

Key Words: acetic acid, fermentation, lactic acid, microbiology, temperature

\section{Introdução}

A utilização de aditivos em silagens de gramíneas do gênero Panicum pode melhorar a qualidade do processo fermentativo. Os inoculantes microbianos são muito utilizados em todo o mundo, em virtude da segurança e facilidade de uso, além de não serem corrosivos e não poluírem o ambiente. Existe grande número de estudos sobre o uso de

Este artigo foi recebido em 11/5/2007 e aprovado em 8/9/2008.

Correspondências devem serenviadas para:csilva_avila@hotmail.com 
inoculantes em silagens, no entanto, os resultados relacionados às melhorias do processo fermentativo, ao valor nutritivo, ao consumo de matéria seca e ao ganho de peso dos animais ainda são contraditórios.

Em silagens de gramíneas, cuja concentração de carboidratos solúveis geralmente é baixa, a adição de bactérias do ácido lático reduz mais rapidamente o $\mathrm{pH}$ das silagens, inibindo o crescimento de microrganismos que podem causar problemas aos animais e ao homem, como enterobactérias e bactérias dos gêneros Listeria e Clostridium, melhorando a qualidade fermentativa e sanitária durante os processos aeróbio e anaeróbio (Bolsen, 1995).

Até alguns anos atrás, a maioria dos inoculantes microbianos existentes no mercado continha somente bactérias láticas homofermentativas, mais eficientes na redução do $\mathrm{pH}$ e que restringem a degradação protéica, reduzindo as perdas de MS durante o processo fermentativo. No entanto, estudos comprovam que silagens bem preservadas apresentam maiores problemas de deterioração aeróbia, que se inicia com a entrada de oxigênio no silo, o que proporciona o crescimento de microrganismos aeróbios facultativos, aumentando a temperatura e as perdas de nutrientes das silagens (Nishino et al., 2002).

Diante disso, trabalhos têm sido realizados para avaliar a utilização de L. buchneri em silagens como forma de aumentar a estabilidade aeróbia em maior teor de ácido acético e menor contagem de leveduras. Segundo Danner et al. (2003), a atividade antimicrobiana do acetato ou lactato é causada por moléculas ácidas não dissociadas lipofílicas que penetram no plasma da membrana bacteriana e prejudicam o crescimento microbiano. No Brasil, existem poucos inoculantes comerciais que contenham esta bactéria e os existentes possuem cepas isoladas de plantas de clima temperado. Nesta pesquisa, avaliou-se o efeito da adição de duas cepas de L. buchneri, uma proveniente de um inoculante comercial e outra isolada de silagem de cana-de-açúcar (Saccharum spp.), sobre a estabilidade aeróbia de silagens de capim-mombaça após a abertura dos silos.

\section{Material e Métodos}

O experimento foi conduzido nos Departamentos de Zootecnia e Biologia da Universidade Federal de Lavras, Minas Gerais, em área de capim-mombaça (Panicum maximum Jacq. cv. Mombaça) já estabelecida. Com base na análise química do solo, foi feita a correção da acidez, após corte de uniformização, para elevar a saturação por bases para $60 \%$. Em janeiro de 2006, foi feito corte de uniformização com roçadeira costal a aproximadamente $20 \mathrm{~cm}$ do nível do solo, seguido da adubação, conforme recomendação da Comissão de Fertilidade do Solo do Estado de Minas Gerais (1999). Após 60-65 dias de rebrota, a forragem foi colhida com roçadeira costal e picada em máquina estacionária, em partículas de 10 a $30 \mathrm{~mm}$ para ensilagem.

Os inoculantes foram previamente preparados no Laboratório de Microbiologia do Departamento de Biologia da UFLA. O inoculante experimental consistiu da bactéria Lactobacillus buchneri (UFLA SIL 72), isolada de uma silagem de cana-de-açúcar (Ávila, 2007), enquanto o inoculante comercial empregado foi o inoculante Pioneer 11 A44TM (Pioneer Hi-Bred International, Inc., Des Moines, IA, USA), que contém a bactéria L. buchneri na concentração $10^{11} \mathrm{ufc} / \mathrm{g}$ do produto.

O inoculante comercial foi adicionado de acordo com a recomendação do fabricante, de $5 \mathrm{log}$ ufc/g de forragem. Para isso, 0,003 $\mathrm{g}$ do inoculante foi pesado, misturado a $80 \mathrm{~mL}$ de água destilada estéril e posteriormente borrifado sobre a forragem no momento da ensilagem. Para que ambos fossem adicionados em mesma concentração de células viáveis, foi feita contagem do número destas células no inoculante experimental por meio de plaqueamento em meio MRS (Mann Rogosa Sharpe). Inicialmente o microrganismo foi cultivado em tubos contendo $2 \mathrm{~mL}$ de caldo MRS por 24 horas; depois foi transferido para tubos contendo $10 \mathrm{~mL}$ de caldo MRS por mais 24 horas e, finalmente, transferido para erlenmeyer com $250 \mathrm{~mL}$ de caldo MRS e cultivado por 24 horas. Seqüencialmente, foi feita contagem do número de células, obtendo-se um resultado de $9 \log$ ufc/mL do caldo. Para cada silo foi retirado então $0,3 \mathrm{~mL}$ do caldo presente no erlenmeyer, que foi posteriormente misturado a $80 \mathrm{~mL}$ de água destilada estéril e borrifado sobre $3 \mathrm{~kg}$ de forragem para ser ensilada. Ao final, o inoculante experimental foi inoculado em concentração de $5 \log$ ufc/g de forragem.

A forragem picada foi ensilada em silos de PVC com $10 \mathrm{~cm}$ de diâmetro e $80 \mathrm{~cm}$ de altura, adaptados com válvula tipo Bunsen com capacidade para 2,5 a $3 \mathrm{~kg}$ de forragem, em densidade de aproximadamente $600 \mathrm{~kg}$ de forragem por $\mathrm{m}^{3}$. Antes da ensilagem, foram retiradas amostras da forragem, que foram encaminhadas ao Laboratório de Pesquisa Animal do Departamento de Zootecnia - UFLA para análise da composição químico-bromatológica. Para análise, as amostras foram secas em estufa com ventilação forçada a $65^{\circ} \mathrm{C}$, trituradas em moinho do tipo Willey com peneira de 30 mesh e armazenadas em potes plásticos para determinação dos teores de matéria seca (MS) e proteína bruta (PB), conforme métodos recomendados pela AOAC (1990), 
fibra em detergente neutro (FDN) e fibra em detergente ácido (FDA), segundo técnicas descritas por Silva (1990), carboidratos solúveis (CHO), conforme metodologia de Bailey (1977), modificada por Valadares Filho (1981), e poder tampão, segundo Playne \& McDonald (1966).

Os inoculantes preparados anteriormente foram misturados à forragem no momento da ensilagem, com auxílio de um borrifador (sendo um para cada silagem), procurando-se adicionar à silagem testemunha somente água destilada estéril, na mesma quantidade de água adicionada aos inoculantes $(80 \mathrm{~mL})$. A forragem foi compactada manualmente com auxílio de uma barra de ferro nos silos, que foram armazenados em temperatura ambiente e sob proteção da luz solar e de chuvas.

Após um período de armazenamento de 90 dias, os silos foram abertos e de cada um foram retiradas três amostras. Dessas amostras, uma parte (100 g) foi colocada em sacos plásticos devidamente identificados e congelado. Posteriormente extraiu-se o suco, com prensa hidráulica, para determinação do teor de nitrogênio amoniacal, em porcentagem do nitrogênio total [ $\mathrm{N}-\mathrm{NH}_{3}(\% \mathrm{~N}$ total)], e dos ácidos acético, propiônico, butírico e lático, por cromatografia gasosa (AOAC, 1980). Na análise cromatográfica, utilizou-se o cromatógrafo Shimadzu GC17a; Coluna capilar $(30 \mathrm{~m} \times$ $0,025 \mathrm{~mm}$ ), com temperatura inicial de $90^{\circ} \mathrm{C}$ e final de $180^{\circ} \mathrm{C}$, pressão de 22 e fluxo de 20 (AOAC, 1980).

A outra amostra de $80 \mathrm{~g}$ foi coletada e colocada em frascos contendo $720 \mathrm{~mL}$ de água peptonada estéril (1\% de peptona), esterilizada (a $121^{\circ} \mathrm{C} / 15$ minutos) e agitada durante 20 minutos. A partir do extrato obtido, foram preparadas diluições decimais de $10^{-1}$ a $10^{-6}$ para avaliação das populações de bactérias do ácido lático, leveduras e fungos filamentosos. As contagens totais dos microrganismos foram realizadas tomando-se $0,1 \mathrm{~mL}$ de cada diluição, em triplicata, espalhando com alça de Drigalsky no meio MRS, acrescido de nistatina $(0,4 \%)$, para contagem de bactérias láticas; meio DRBC (Dicloran Rosa Bengala Cloranfenicol) para a contagem de fungos filamentosos e meio YEPG para a contagem de leveduras. As placas foram incubadas a $28^{\circ} \mathrm{C}$ e a contagem total de bactérias foi realizada após 24-72 horas de incubação. Para contagem de fungos filamentosos e leveduras, as placas foram incubadas por 24-72 horas. Também foi retirada uma subamostra de $10 \mathrm{~g}$ para preparo dos extratos e leitura do $\mathrm{pH}$, em potenciômetro DIGIMED®DM20. Uma terceira amostra de aproximadamente $100 \mathrm{~g}$ foi retirada para análise dos teores de matéria seca, proteína bruta e carboidratos solúveis, segundo as técnicas descritas anteriormente.

Todo o conteúdo de silagem restante $(2,0$ a $2,5 \mathrm{~kg})$ foi acondicionado em baldes plásticos de aproximadamente
$5,0 \mathrm{~kg}$, onde permaneceu por dez dias, para avaliação da estabilidade aeróbia. Essas amostras foram mantidas em sala fechada onde foi monitorada a temperatura de cada amostra diariamente. Para isso, um termômetro de mercúrio foi inserido na massa ensilada, em profundidade de $10 \mathrm{~cm}$, durante dez dias, para tomada de temperatura duas vezes ao dia (às 8 e 17 h). A temperatura ambiente foi medida com o auxílio de um termômetro localizado próximo aos baldes; a média registrada foi de $20,5^{\circ} \mathrm{C}$ e a variação, entre 19 e $21^{\circ} \mathrm{C}$. A estabilidade aeróbia foi calculada como o tempo, em horas, para que as silagens, após a abertura do silo, apresentassem temperatura $2^{\circ} \mathrm{C}$ mais elevada que a temperatura ambiente (Kung Jr. et al., 2000).

Durante o período em que as silagens foram mantidas nos baldes, nos dias 0 (abertura dos silos) 2, 6 e 10, foram retiradas amostras para as análises químico-bromatológicas e microbiológicas das silagens, pelas mesmas técnicas descritas anteriormente.

O experimento foi conduzido em delineamento inteiramente casualizado, com três repetições, empregando-se esquema de parcelas subdivididas, de modo que os tratamentos (silagens sem inoculantes, com inoculante experimental e com inoculante comercial) foram aleatorizados nas parcelas e os tempos de avaliação (0, 2, 6 e 10 dias após abertura dos silos) nas subparcelas. Os dados foram analisados estatisticamente pelos procedimentos de análise de variância sugeridos por Steel et al. (1997) para os experimentos em parcelas subdivididas quando as parcelas são medidas no tempo utilizando o programa SISVAR (Ferreira, 2000). Aqueles de natureza qualitativa (tratamentos para ensilagem) foram comparados pelo teste Scott-Knott e os de natureza quantitativa (tempos de avaliação) foram submetidos ao estudo de regressão.

\section{Resultados e Discussão}

À exceção dos valores de fibra em detergente ácido (FDA) e hemicelulose, a adição do inoculante L. buchneri não influenciou a composição química do capim-mombaça antes da ensilagem (Tabela 1). Esse efeito, entretanto, está relacionado a erros de amostragem, pois não existe nenhuma característica nos inoculantes que possa causar variação nos teores de FDA ou hemicelulose antes da ensilagem.

A composição química da forragem antes da ensilagem apresentou valores semelhantes aos encontrados na literatura, com pequenas variações, mas em geral coerentes com os relatados para gramíneas da espécie Panicum maximum com 60 dias de idade (Tabela 1). Coan et al. (2005) encontraram valores semelhantes de 
Tabela 1 - Composição química e poder tampão do capimmombaça antes da ensilagem

\begin{tabular}{lccc}
\hline & $\begin{array}{c}\text { Sem } \\
\text { inoculante }\end{array}$ & $\begin{array}{c}\text { Inoculante } \\
\text { experimental }\end{array}$ & $\begin{array}{c}\text { Inoculante } \\
\text { comercial }\end{array}$ \\
\hline Matéria seca (\%) & $28,0 \mathrm{a}$ & $28,3 \mathrm{a}$ & $28,2 \mathrm{a}$ \\
Proteína bruta (\%) & $7,8 \mathrm{a}$ & $7,5 \mathrm{a}$ & $7,7 \mathrm{a}$ \\
Fibra em detergente & $77,9 \mathrm{a}$ & $77,9 \mathrm{a}$ & $78,6 \mathrm{a}$ \\
neutro (\%) & & & \\
Fibra em detergente & $50,0 \mathrm{a}$ & $43,2 \mathrm{c}$ & $46,7 \mathrm{~b}$ \\
ácido (\%) & & & \\
Hemicelulose (\%) & $30,6 \mathrm{~b}$ & $35,0 \mathrm{a}$ & $32,0 \mathrm{~b}$ \\
Carboidratos solúveis (g/kg) & $25,3 \mathrm{a}$ & $24,1 \mathrm{a}$ & $26,6 \mathrm{a}$ \\
Poder tampão & 24,3 & 22,8 & 21,9 \\
(Emg NaOH/100g MS) & & & \\
\hline
\end{tabular}

Médias com letras diferentes diferem $(\mathrm{P}<0,05)$ estatisticamente, nas colunas, pelo teste Scott-Knott.

matéria seca $(25,1 \%)$, mas relataram para o capim-mombaça colhido aos 60 dias teores de carboidratos solúveis ( $124 \mathrm{~g} / \mathrm{kg}$ de MS) e poder tampão (20,9 emg de NaOH/100 g de MS) superiores aos deste estudo. Os teores de carboidratos solúveis, matéria seca e poder tampão servem para avaliar a viabilidade de ensilagem de uma forrageira. Segundo McDonald et al. (1991), quanto menor a relação carboidratos solúveis/poder tampão, maior a concentração de matéria seca requerida para evitar fermentações indesejáveis. A relação carboidratos solúveis/poder tampão neste trabalho variou de 1,05 a 1,2, valores relativamente baixos para resultar em rápida redução do $\mathrm{pH}$ durante a fermentação.

Em trabalho realizado por Ávila et al. (2006), a relação carboidratos solúveis/poder tampão encontrada para o capim-tanzânia com 60 dias de crescimento foi de 1,64. Este valor mais alto para o capim-tanzânia em comparação ao capim-mombaça foi resultado do menor poder tampão (15,74 Emg de NaOH/100 g de MS) do capim-tanzânia.

Em todas as silagens, os teores de MS após abertura dos silos aumentaram, havendo interação significativa $(\mathrm{P}<0,01)$ inoculante $\times$ tempo de exposição ao ar (Tabela 2). A silagem com inoculante comercial apresentou aumento linear de $0,6 \%$ de MS por dia (Tabela 2), enquanto as silagens testemunha e com inoculante experimental apresentaram aumento até os valores máximos de 33,38 e 30,58\% aos 5 e 4 dias, respectivamente. O aumento nos teores de MS após abertura dos silos pode ser explicado, em princípio, pela desidratação do material ensilado e pela conseqüente evaporação da água. No entanto, com o aumento do tempo de exposição ao ar, ocorre oxidação dos nutrientes solúveis ou consumo dos ácidos graxos voláteis por microrganismos deterioradores e, assim, forma-se a chamada "água de metabolismo" (Woolford, 1984). Este fato pode ocasionar novamente redução dos teores de MS, como observado nas silagens testemunha e com inoculante experimental, a partir de 4 a 5 dias, respectivamente, quando houve pequena redução nos teores de MS.

Os teores de PB e carboidratos solúveis, no entanto, não foram influenciados pelas silagens nem pelos tempos de avaliação (Tabela 2). Esperava-se redução nos teores de PB e carboidratos solúveis durante a exposição ao ar, no entanto, isso não ocorreu (Tabela 2). Uma explicação para a manutenção dos teores de proteína bruta seria a concentração deste componente com o aumento do teor de MS e

Tabela 2 - Composição química das silagens de capim-mombaça após 90 dias de fermentação

\begin{tabular}{|c|c|c|c|c|c|}
\hline \multirow[t]{2}{*}{ Silagem } & \multicolumn{4}{|c|}{ Dias após abertura dos silos } & \multirow[t]{2}{*}{ Equação de regressão } \\
\hline & 0 & 2 & 4 & 6 & \\
\hline \multicolumn{6}{|c|}{ Matéria seca $(\%)$} \\
\hline $\begin{array}{l}\text { Sem inoculante } \\
\text { Inoculante experimental } \\
\text { Inoculante comercial }\end{array}$ & $\begin{array}{l}28,59 \mathrm{a} \\
27,54 \mathrm{a} \\
27,45 \mathrm{a}\end{array}$ & $\begin{array}{l}32,22 \mathrm{a} \\
31,06 \mathrm{a} \\
28,35 \mathrm{~b}\end{array}$ & $\begin{array}{l}32,35 \mathrm{a} \\
30,40 \mathrm{a} \\
29,92 \mathrm{a}\end{array}$ & $\begin{array}{l}29,93 \mathrm{~b} \\
28,75 \mathrm{~b} \\
33,16 \mathrm{a}\end{array}$ & \multirow[t]{2}{*}{$\begin{array}{c}Y_{1}=-0,155 x^{2}+1,589 x+29,31 ; R^{2}=76,38 \% \\
Y_{2}=-0,014 x^{2}+1,18 x+28,10 ; R^{2}=74,44 \% \\
Y_{3}=0,557 x+27,21 ; R^{2}=89,99 \%\end{array}$} \\
\hline \multicolumn{5}{|c|}{ Proteína bruta (\%) } & \\
\hline $\begin{array}{l}\text { Média } \\
\text { pH }\end{array}$ & 6,87 & 6,96 & 6,63 & 6,41 & Não-significativo \\
\hline Média & 4,73 & 4,70 & 5,24 & 6,88 & \multirow[t]{3}{*}{$y=0,215 x+4,424 ; \quad R^{2}=86,18 \%$} \\
\hline \multirow{3}{*}{ Média } & \multicolumn{4}{|c|}{ Carboidratos solúveis $(\mathrm{g} / \mathrm{kg})$} & \\
\hline & 3,80 & 3,63 & 3,43 & 4,00 & \\
\hline & \multicolumn{4}{|c|}{ Nitrogênio amoniacal, $\mathrm{NH}_{3}(\% \mathrm{~N}$-total $)$} & \\
\hline $\begin{array}{l}\text { Sem inoculante } \\
\text { Inoculante experimental } \\
\text { Inoculante comercial }\end{array}$ & $\begin{array}{l}39,95 \mathrm{~b} \\
28,98 \mathrm{c} \\
51,28 \mathrm{a}\end{array}$ & $\begin{array}{l}28,27 \mathrm{~b} \\
29,57 \mathrm{~b} \\
37,11 \mathrm{a}\end{array}$ & $\begin{array}{l}28,35 \mathrm{~b} \\
31,58 \mathrm{a} \\
31,58 \mathrm{a}\end{array}$ & $\begin{array}{l}33,41 \mathrm{~b} \\
34,28 \mathrm{~b} \\
35,55 \mathrm{a}\end{array}$ & $\begin{array}{c}\mathrm{Y}_{1}=0,391 \mathrm{x}^{2}-4,343 \mathrm{x}+38,64 ; \mathrm{R}^{2}=82,89 \\
\mathrm{Y}_{2}=0,573 \mathrm{x}+28,69 ; \mathrm{R}^{2}=98,33 \% \\
\mathrm{Y}_{3}=0,484 \mathrm{x}^{2}-6,238 \mathrm{x}+50,01 ; 2=95,55 \%\end{array}$ \\
\hline
\end{tabular}

Médias com letras diferentes nas colunas diferem significativamente $(\mathrm{P}<0,05)$ entre silagens quanto à mesma variável.

NS = Não-significativo. 
a redução dos teores de ácidos graxos voláteis. No caso dos teores de carboidratos solúveis, como a concentração residual foi muito baixa (3,8 g/kg de MS), esta redução não foi detectada estatisticamente.

Os valores de $\mathrm{pH}$ sofreram efeito significativo somente dos tempos de avaliação, uma vez que as três silagens tiveram mesmo comportamento em todo o tempo de avaliação aeróbica das silagens, ou seja, aumento linear significativo $(\mathrm{P}<0,01)$ de 0,2 unidades nos valores de $\mathrm{pH}$ por dia (Tabela 2). O aumento do $\mathrm{pH}$ foi ocasionado pela redução dos ácidos orgânicos, que provavelmente foram utilizados no metabolismo dos microrganismos de deterioração aeróbia.

As variações nas concentrações de $\mathrm{NH}_{3}$ (\% N-Total) diferiram entre silagens, o que comprova interações significativas dos fatores estudados (Tabela 2). No momento de abertura dos silos, todas as silagens apresentaram altos valores de $\mathrm{NH}_{3}$ (\% $\mathrm{N}$-Total), que foram maiores para as silagens com inoculante comercial, seguidas pela silagem testemunha e pela silagem com inoculante experimental. Esses valores indicam alta proteólise durante a fermentação e são resultado principalmente da redução lenta e insuficiente do $\mathrm{pH}$, que, por sua vez, resulta principalmente da baixa concentração de carboidratos solúveis da forragem. A partir deste momento, o tempo de observação teve efeito quadrático sobre os valores de $\mathrm{NH}_{3}$ das silagens testemunha e com inoculante comercial, cujos valores mínimos foram de 26,6 e $30 \%$ aos 5,5 e 6,5 dias, respectivamente, após abertura dos silos. Na silagem tratada com inoculante experimental, foi observado aumento linear $(\mathrm{P}<0,01)$ de 0,6 unidades percentuais de $\mathrm{NH}_{3}$ por dia no intervalo de tempo estudado. Apesar do pequeno aumento na concentração de $\mathrm{NH}_{3}$ das silagens com o inoculante experimental, não foram observados aumentos significativos desse composto nas silagens após a abertura dos silos. Ao contrário, notou-se redução da concentração de $\mathrm{NH}_{3}$ nas silagens inoculadas que apresentavam teores elevados no momento de abertura dos silos (Tabela 2).

Guim et al. (2002) não observaram diferenças nos valores de $\mathrm{pH}$ e $\mathrm{NH}_{3}$ de silagens de capim-elefante com e sem inoculantes após 8 dias de abertura dos silos, mas relataram que os valores médios de $\mathrm{pH}$ aumentaram de 3,97 para 8,33 e os de $\mathrm{NH}_{3}$ reduziram durante esse período. Outros autores também observaram redução dos teores de $\mathrm{NH}_{3}$ em silagens com o aumento do tempo de exposição ao ar (Bernardes, 2006; Tavares, 2005). Reduções na concentração de $\mathrm{NH}_{3}$ após abertura dos silos podem ser atribuídas à volatilização da amônia ou à imobilização de nitrogênio pelos fungos miceliares. Esta imobilização do $\mathrm{NH}_{3}$ ocorre por meio das hifas dos fungos, que crescem com maior rapidez após abertura dos silos. Uma vez que a determinação do $\mathrm{NH}_{3}$ é feita no suco da silagem, essa imobilização de nitrogênio pelas hifas dos fungos filamentosos dificultaria sua passagem para o líquido da silagem (Guim et al., 2002).

As populações de bactérias láticas, leveduras e fungos filamentosos após a abertura dos silos foram influenciadas $(\mathrm{P}<0,01)$ pela interação inoculante $\times$ tempos de abertura dos silos. As populações dessas bactérias nas silagens com inoculante aumentaram de forma quadrática, com valores máximos de 9,7 e 9,2 log ufc/g de silagem aos 8 e 6 dias para as silagens com os inoculantes experimental e comercial, respectivamente (Figura 1A). Para a silagem controle, nenhuma equação ajustou-se às modificações temporais ocorridas na população de bactérias láticas após a abertura dos silos; houve redução até dois dias de exposição ao ar e, em seguida, aumento até seis dias, quando os valores estabilizaram (Figura 1A).

A população de leveduras da silagem controle, que era mais baixa no momento de abertura dos silos, aumentou linearmente $(\mathrm{P}<0,01)$ com o tempo de exposição ao ar. Nas silagens com os inoculantes experimental e comercial, as populações desses microrganismos aumentaram de forma quadrática com os tempo de exposição ao ar, com valores máximos de 7,7 e 8,2 log ufc/g de silagem aos 8 e 7 dias, respectivamente (Figura $1 \mathrm{~B}$ ).

No momento de abertura dos silos, a silagem sem inoculante e aquela com inoculante experimental proporcionaram mais altas contagens de fungos filamentosos. Com a exposição ao ar, a população desses fungos na silagem controle alcançou contagem mínima de $3 \mathrm{log}$ da ufc/g de silagem aos dois dias após abertura dos silos, com subseqüente aumento. Na silagem com o inoculante experimental, houve redução na contagem destes microrganismos com dois dias de exposição ao ar. Até este momento, não havia sido observado crescimento de fungos filamentosos nas silagens inoculadas com inoculante comercial, que, após este ponto, aumentou até dez dias de exposição ao ar (Figura 1C).

A interação inoculante $\times$ tempo teve efeito sobre os teores dos ácidos acético, propiônico e lático. Por sua vez, o ácido butírico foi influenciado apenas pelo tempo de exposição ao ar. A concentração de ácido acético decresceu linearmente $(\mathrm{P}<0,01)$ nas silagens com inoculantes experimental e comercial, enquanto a silagem testemunha se comportou de forma quadrática em relação ao tempo de exposição ao ar (Figura 2A). As concentrações de ácido propiônico e butírico decresceram de forma linear com o tempo de exposição ao ar (Figuras 2B e C).

Os valores de ácido lático ajustaram-se a modelos quadráticos para a silagem controle e aquela com inoculante 

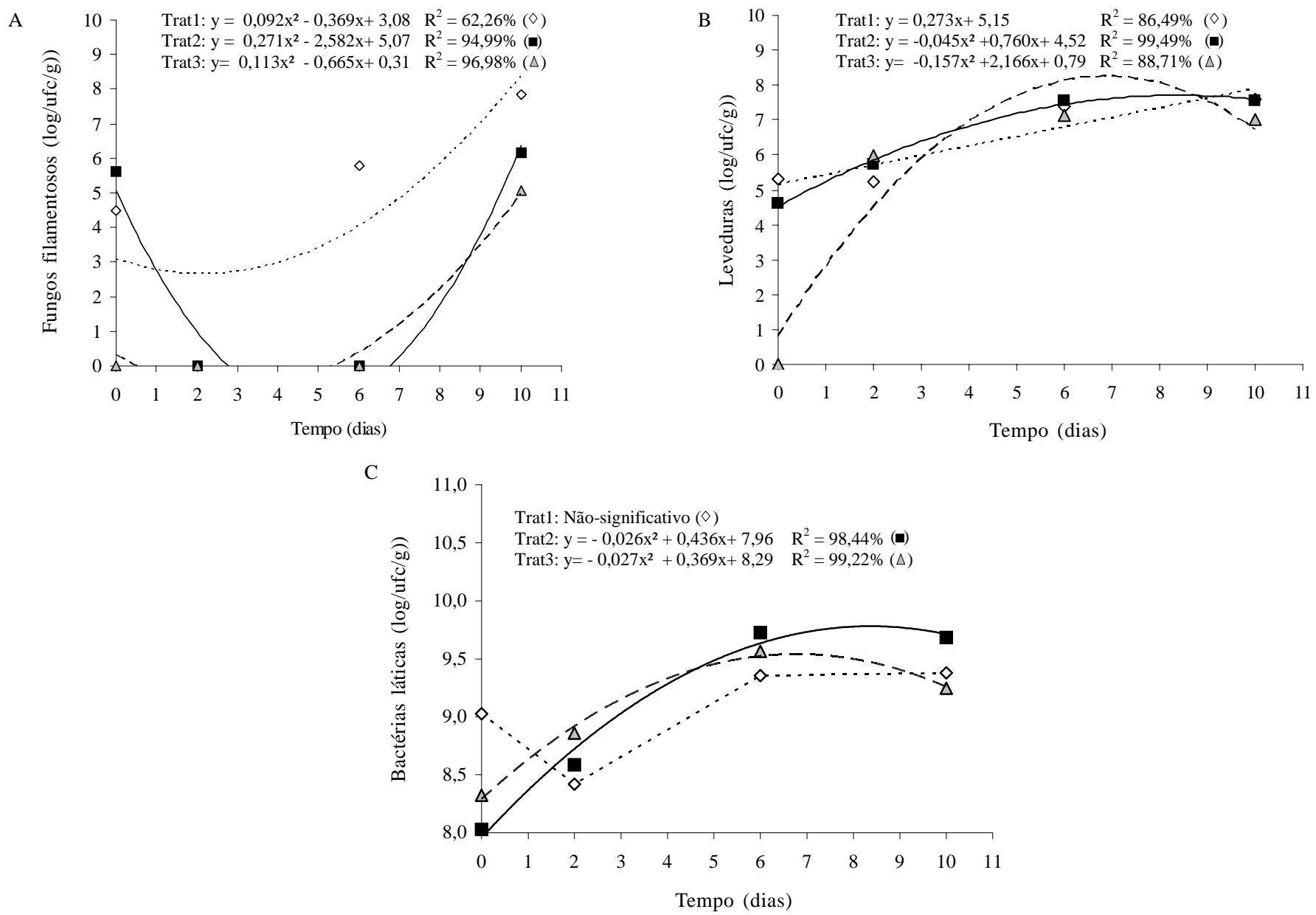

Figura 1 - Contagem de bactérias láticas (A), leveduras (B) e fungos filamentosos (C) em silagens de capim-mombaça sem inoculante ( $\left.\mathrm{Y}_{1}\right)$ e com inoculantes experimental $\left(\mathrm{Y}_{2}\right)$ e comercial $\left(\mathrm{Y}_{3}\right)$ após a abertura dos silos.

comercial. Por outro lado, a silagem com inoculante experimental não se ajustou a nenhuma equação (Figura 2D).

Neste trabalho, houve crescimento tanto de bactérias láticas quanto de leveduras e fungos filamentosos após a abertura dos silos, o que indica que esses microrganismos podem estar envolvidos na deterioração aeróbia das silagens. No início do processo de exposição ao ar, o crescimento de leveduras e algumas bactérias que utilizam ácidos orgânicos, como o ácido lático, deve ter ocorrido principalmente às custas desses produtos do metabolismos das próprias bactérias do ácido lático, pois a concentração de carboidratos residuais era muito baixa (Tabela 2), o que pode ser comprovado pelas reduções nas concentrações dos ácidos acético e lático (Figuras 2A e D).

O lactato pode ser metabolizado por bactérias láticas sob condições aeróbias e anaeróbias. É o que ocorre com a espécie L. buchneri, que degrada ácido lático a ácido acético e 1,2-propanodiol (Oude-Elferink et al., 2001). Desta forma, as bactérias láticas também estão envolvidas na deterioração aeróbia de silagens e, sob condições aeróbias, muitas espécies de leveduras degradam o ácido lático, causando aumento do $\mathrm{pH}$ da silagem e proporcionado condições para que outros microrganismos deterioradores se desenvolvam (McDonald et al., 1991).

Os fungos filamentosos crescem melhor sob condições aeróbias e pH mais alto $(5,0$ a 6,0$)$. Assim, quando o silo é aberto, ocorre aumento do $\mathrm{pHe}$ da concentração de oxigênio, permitindo o crescimento desses microrganismos capazes de degradar ampla variedade de nutrientes, inclusive carboidratos estruturais e lignina. Desse modo, a degradação de compostos complexos pode liberar substratos para que as bactérias láticas e leveduras continuem crescendo (Winters et al., 1987).

A população de fungos filamentosos na silagem com inoculante comercial manteve-se abaixo do nível detectável até aos seis dias após abertura dos silos, quando aumentou (Figura 1C). Apesar da alta concentração de ácido acético no momento de abertura dos silos, esse ácido sozinho não foi responsável pela inibição do crescimento daqueles microrganismos, uma vez que esse efeito não foi verificado 

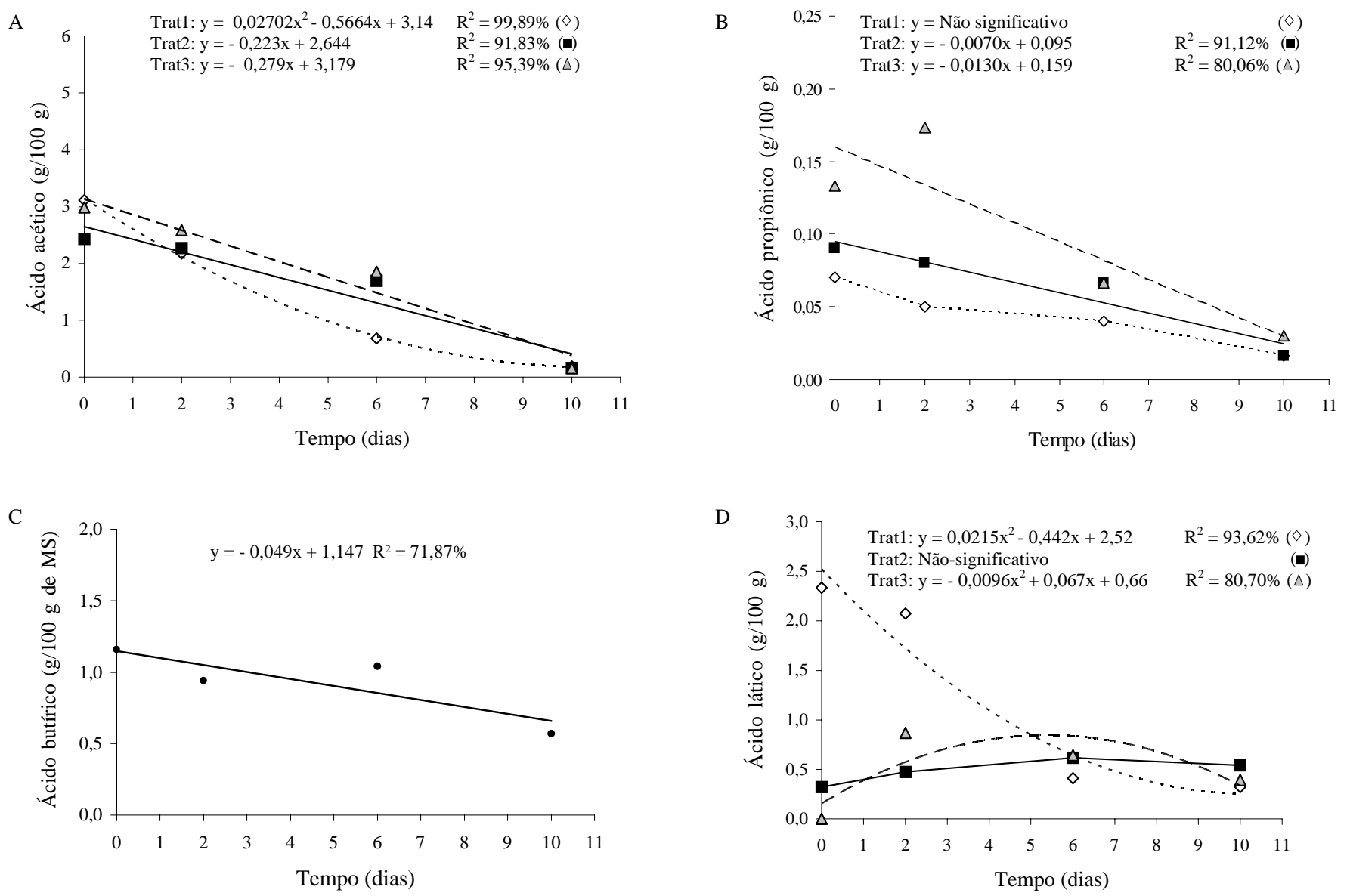

Figura 2 - Concentração de ácido acético (A), ácido propiônico (B), ácido butírico (C) e ácido lático (D) das silagens de capim-mombaça sem inoculante $\left(\mathrm{Y}_{1}\right)$ e com inoculantes experimental $\left(\mathrm{Y}_{2}\right)$ e comercial $\left(\mathrm{Y}_{3}\right)$ após a abertura dos silos.

na silagem com inoculante experimental nos primeiros dois dias. No entanto, a concentração de ácido propiônico nessa silagem, aproximadamente $0,16 \mathrm{~g} / 100 \mathrm{~g}$ de MS, foi mais alta que o valor encontrado na silagem com inoculante experimental, de aproximadamente $0,09 \mathrm{~g} / 100 \mathrm{~g}$ de MS (Figura 1B), assim, a associação entre os dois ácidos pode ter sido responsável pela inibição do crescimento de fungos filamentosos. O efeito dos ácidos acético e propiônico em inibir o crescimento de leveduras foi observado em trabalho conduzido por Moon (1983) com culturas in vitro. A partir do estudo de sinergismo entre os compostos, esse autor verificou que altas concentrações de ácido lático e baixas de ácido acético aumentaram significativamente o crescimento de leveduras. Além disso, a mistura dos ácidos acético e propiônico (concentração acima de $10 \mathrm{mM}$ ) foi, entre as misturas estudadas, a mais eficiente em reduzir a taxa de crescimento de leveduras ( $50 \%$ de inibição).

Guim et al. (2002) observaram aumento e posterior redução na população de fungos filamentosos em silagens de capim-elefante durante a exposição ao ar e atribuíram esta variação ao ciclo de vida dos fungos filamentosos. $\mathrm{O}$ pH ótimo para crescimento dos fungos é de 5-6 e a seqüência normal de reprodução é: esporo - esporo com tubo germinativo-hifa-micélio (conjunto de hifas) órgãos de frutificação - novos esporos. Para que o fungo produza seus órgãos de frutificação, são necessários 3 a 14 dias, dependendo da espécie (Ruiz, 1992). Assim, pode-se inferir que a contagem de fungos filamentosos na abertura dos silos, considerando a ausência de oxigênio, foi de esporos. A redução na contagem após a abertura dos silos, até seis dias de exposição ao ar, pode estar relacionada ao próprio metabolismo desses microrganismos.

A temperatura da silagem sem inoculante foi $2^{\circ} \mathrm{C}$ superior à temperatura ambiente às 55 horas após abertura dos silos (Figura 3A), no entanto, as silagens inoculadas não ultrapassaram essa temperatura limite e não perderam a estabilidade no período estudado, que foi de 240 horas (10 dias) (Figura 3B).

Conforme observado pela equação de regressão (Figura 3A), silagem sem aditivo manteve estabilidade 
A

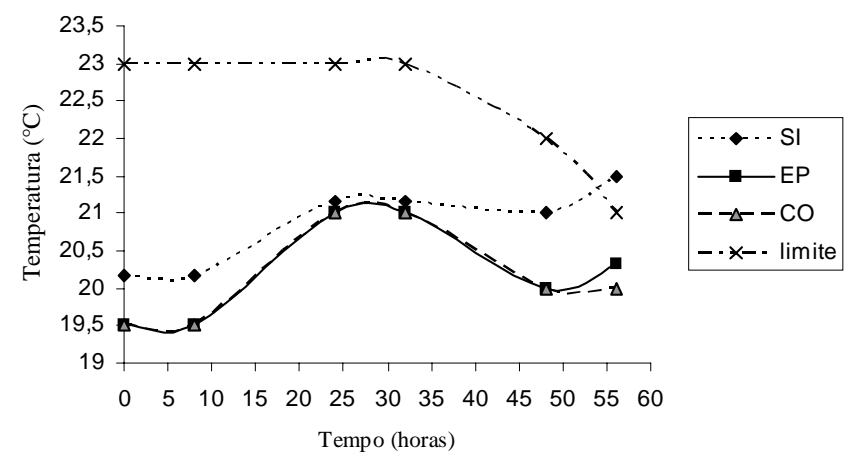

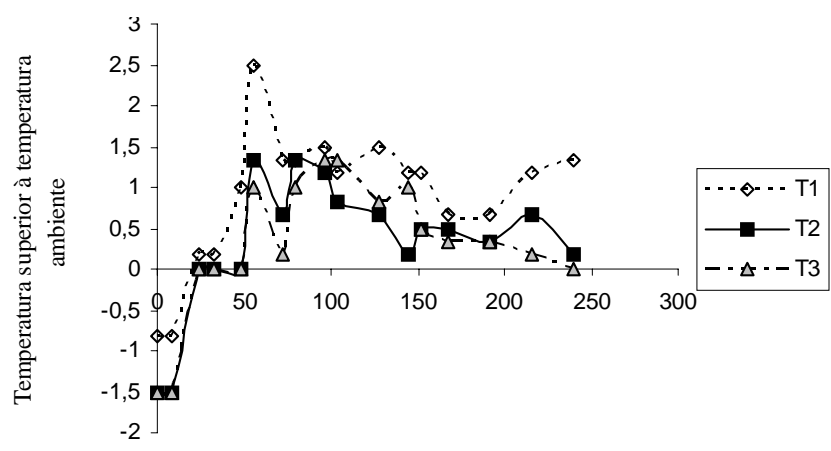

Tempo (horas)

Figura 3 - Temperatura das silagens (A) e dos silos e (B) de capim-mombaça sem inoculante (SI) e com inoculantes experimental (EP) e comercial (CO) após a abertura dos silos.

aeróbia por cerca de 55 horas. Esse tempo, que corresponde a 2,3 dias, indica que, naquele momento, as populações de leveduras e fungos filamentosos (Figuras 1B, C) foram, respectivamente, de 5,7 e 2,7 log da ufc/g de silagem controle; de 6,03 e < 2,0 log da ufc/g de silagem com inoculante experimental e de 4,94<2,0log da ufc/g de silagem com inoculante comercial. Conforme mencionado sobre os crescimento de bactérias láticas e leveduras, os fungos filamentosos foram os principais microrganismos responsáveis pela perda de estabilidade da silagem sem inoculante.

Outros autores também registraram aumento da estabilidade de silagens com a inoculação de L. buchneri. A adição de L. buchneri na dose de $3 \times 10^{5} \log$ da ufc/g a silagem de azevém perene aumentou a estabilidade tanto em silos de laboratório quanto em silos de escala de fazenda (Driehuis et al., 2001). Filya et al. (2003) avaliaram a estabilidade com base nos valores de $\mathrm{pH}$, produção de $\mathrm{CO}_{2} / \mathrm{kg}$ de $\mathrm{MS}$ e contagem de leveduras e mofos após cinco dias de exposição ao ar e relataram que a adição de L. buchneri resultou em menor $\mathrm{pH}(4,7$ vs 6,5$)$, menor produção de $\mathrm{CO}_{2}(20 \mathrm{~g} / \mathrm{kg}$ vs $55 \mathrm{~g} / \mathrm{kg})$ e menor contagem de leveduras (2,6 vs 6,7 log da ufc/g de silagem) em relação à silagem controle. Kleinschmit et al. (2006) avaliaram resultados da inoculação com L. buchneri em 43 experimentos com 23 fontes de informação, por meio de meta análise, e concluíram que em gramíneas a inoculação melhorou a estabilidade aeróbia em 20 horas nas silagens tratadas com $5 \mathrm{log}$ ufc/g ou menos de L. buchneri e em 40 horas naquelas com mais que $5 \mathrm{log}$ ufc/g de forragem.

Nesta pesquisa, a adição de L. buchneri melhorou a estabilidade das silagens, pois não houve aquecimento durante todo o período avaliado. Esse resultado foi conse- qüência de uma associação de resultados, ou seja, altas concentrações de ácido acético, associado ao ácido propiônico e menor concentração de ácido lático, que serviu como substrato para o crescimento de microrganismos deterioradores. A silagem sem inoculante, apesar de ter ultrapassado a temperatura limite, não aqueceu muito, possivelmente por causa da baixa concentração de carboidratos solúveis residuais. Deve-se considerar que essas silagens foram de baixa qualidade fermentativa, em razão das características da forragem original, que apresentou baixa concentração de carboidratos solúveis e alto poder tampão. Com isso, as silagens resultantes apresentaram altas concentrações de $\mathrm{NH}_{3}$, acima de $28 \%$ do nitrogênio total e ácido butírico, que são indicativos de crescimento de bactérias do gênero clostridium. No entanto, a adição de L. buchneri a estas silagens é recomendável, pois inibe o crescimento de fungos filamentosos e leveduras nas silagens e aumenta a estabilidade aeróbia. Todavia, essa adição deve ser acompanhada de outros aditivos que forneçam substrato para as bactérias láticas e assim melhore o perfil de fermentação da silagem durante a fase anaeróbica.

\section{Conclusões}

A adição de L. buchneri na ensilagem do capimmombaça influencia o processo fermentativo e inibe o crescimento de fungos filamentosos, principais deterioradores da silagem na fase aeróbia. Apesar de não melhorar a qualidade de fermentação, os inoculantes resultam em silagens mais estáveis, por isso, sua utilização é recomendável somente em conjunto com aditivos fornecedores de substratos para as bactérias do ácido lático. 


\section{Agradecimentos}

Ao CNPq, à FAPEMIG e à CAPES, pelo apoio financeiro.

\section{Literatura Citada}

ASSOCIATION OF OFFICIAL AGRICULTURAL CHEMISTS AOAC. Official methods of analyses. 13.ed. Washington, D.C.: $1980.1015 p$.

ASSOCIATION OF OFFICIAL AGRICULTURAL CHEMISTS AOAC. Official methods of analyses. 15.ed. Virginia: 1990. v. $1,648 \mathrm{p}$.

ÁVILA, C.L.S.; PINTO, J.C.; TAVARES, V.B. et al. Avaliação dos contedos de carboidratos solúveis do capim-tanzânia ensilado com aditivos. Revista Brasileira de Zootecnia, v. 35 , n. 3 , p. 648-654, 2006

ÁVILA, C.L.S. Isolamento e uso de Lactobacillus buchneri na ensilagem de capim-mombaça e cana-de-açúcar. 2007. 175f. Tese (Doutorado em Zootecnia) - Universidade Federal de Lavras, Lavras, 2007.

BERNARDES, T.F. Controle da deterioração aeróbia de silagens. 2006. 103f. Tese (Doutorado em Zootecnia) Universidade Estadual Paulista - Faculdade de Ciências Agrárias e Veterinárias Júlio Mesquita, Jaboticabal, 2006.

BOLSEN, K.K. Silage: basic principles. In: BARNES, R.F.; MILLER, D.A.; NELSON, C.J. (Eds.) Forages. 5.ed. Ames: Iowa State University, 1995. p.163-176.

COAN, R.M.; VIEIRA, P.F.; SILVEIRA, R.N. et al.Inoculante enzimático bacteriano, composição química e parâmetros fermentativos das silagens dos capins Tanzânia e Mombaça. Revista Brasileira de Zootecnia, v.34, n.2, p.416-424, 2005.

COMISSÃO DE FERTILIDADE DO SOLO DO ESTADO DE MINAS GERAIS - CFSEMG. Recomendação para uso de corretivos e fertilizantes de Minas Gerais: $5^{\text {a }}$ aproximação. Viçosa, MG, 1999. 359p.

DANNER, H.; HOLZER, M.; MAYRHUBER, E. et al. Acetic acid increases stability of silage under aerobic conditions. Applied and Environmental Microbiology, v.69, n.1, p.562-567, 2003.

DRIEHUIS, F.; OUDE ELFERINK, S.J.W.H.; Van WIKSELAAR, P.G. Fermentation characteristics and aerobic stability of grass silage inoculated with Lactobacillus buchneri with or without homofermentative lactic acid bacteria. Grass and Forage Science, v.56, n.4, p.330-343, 2001

FERREIRA, D.F. Anlises estatísticas por meio do SISVAR para windows versão 4.0. In: REUNIÃO ANUAL DA REGIÃO BRASILEIRA DA SOCIEDADE INTERNACIONAL DE BIOMETRIA, 45., 2000, São Carlos. Anais... São Carlos: UFSCar, 2000. p.225-258.

FILYA, I. The effect of Lactobacillus buchneri, with or without homofermentative lactic acid bacteria, on the fermentation, aerobic stability and ruminal degradability of wheat, sorghum and maize silages. Journal of Applied Microbiology, v.95, n. 5 , p.1080-1086, 2003
GUIM, A.; ANDRADE, P.; ITURRINO-SCHOCKEN, R.P. et al. Estabilidade aeróbica de silagens de capim-elefante (Pennisetum purpureum, Schum) emurchecido e tratado com inoculante microbiano. Revista Brasileira de Zootecnia, v.31, n.6, p.2176-2185, 2002

KLEINCHMIT, D.H.; KUNG JR., L. A meta analysis of the effects of Lactobacillus buchneri on the fermentation and aerobic stability de corn and grass and small grain silages. Journal of Dayri Science, v.89, n.10, p.4005-4013, 2006.

KUNG JR., L. Aditivos microbianos e químicos para silagem: Efeitos na fermentação e resposta animal. In: WORKSHOP SOBRE MILHO PARA SIlAGEM, 2., 2001, Piracicaba. Anais... Piracicaba: Fundação de Estudos Agrários Luiz de Queiroz, 2001. p.53-74.

McDONALD, P.; HENDERSON, A.R.; HERON, S.J. Biochemistry of silage. 2.ed. Marlow: Chalcombe Publication, 1991. 340p.

MOON, N.J. Inhibition of the growth of acid-tolerant yeasts by acetate, lactate and propionate and their synergistic mixtures. Journal of Applied Bacteriology, v.55, n.3, p.454-460, 1983.

NISHINO, N.; YOSHIDA, M.; SHIOTA, H. et al. Accumulation of 1,2-propanediol and enhancement of aerobic stability in whole crop maize silage inoculated with Lactobacillus buchneri. Journal of Applied Microbiology, v.94, n.5, p.800-807, 2003.

OUDE ELFERINK, S.J.W.H.; KROONEMAN, J.; GOTTSCHAL, J.A. et al. Anaerobic conversion of lactic acid to acetic acid and 1,2-propanediol by Lactobacillus buchneri. Applied and Environmental Microbiology, v.67, n.1, p.125-132, 2001.

PEREIRA, O.G.; GOBBI, K.F.; PEREIRA, D.H. et al. Conservação de forragens como opção para o manejo de pastagens. In: REUNIÃO ANUAL DA SOCIEDADE BRASILEIRA DE ZOOTECNIA, 43., 2006, João Pessoa. Anais... João Pessoa: Sociedade Brasileira de Zootecnia, 2006. (CD-ROM).

PLAYNE, M.J.; McDONALD, P. The buffering constituints of herbage. Journal of Food Science and Agriculture, v.17, n.6, p.264-268, 1966.

RUIZ, R.L. Microbiologia zootécnica. São Paulo: Roca, 1992. $314 \mathrm{p}$.

SILVA, D.J. Análise de alimentos: métodos químicos e biológicos. Viçosa, MG: Editora UFV, 1990. 166p.

STEEL, R.G.D.; TORRIE, J.H.; DICKEY, D.A. Principles and procedures of statistes a biometrical approach. 3.ed. Boston: WCB McGraw-Hill, 1997. 666p.

TAVARES, V.B. Efeito da compactação na qualidade e estabilidade aeróbia da silagem de capim-tanzânia. 2005. 76f. Dissertação (Mestrado em Zootecnia) - Universidade Federal de Lavras, Lavras, 2005.

VALADARES FILHO, S.C. Digestibilidade aparente e locais de digetão da matéria seca, energia e carboidratos de feno de soja perene. 1981. 88f. Tese (Doutorado em Zootecnia) - Escola de Veterinria, Universidade Federal de Minas Gerais, Belo Horizonte, 1981.

WINTERS, A.L.; WHITTAKER, P.A.; WILSON, R.K. Grass and Forrage Science, v.42, n.2, p.191-196, 1987.

WOOLFORD, M.K. The silage fermentation. New York: Marcel Dekker, 1984. 350p 